\title{
From villa to bungalow to jazz modern New Zealand houses between the two world wars
}

\section{WILLIAM TOOMATH}

To most of us, mention of the ordinary New Zealand house of the 1920s would evoke a picture of low gabled bungalows spread across our suburbs and small towns. The term 'Californian bungalow' would probably come to mind. But the questions of how and why this occurred seem seldom to be asked. In order to understand what happened in the design of ordinary New Zealand houses between the two World Wars we need to go back to the styles that existed before World War One, back in fact to the late Victorian scene.

\section{VICTORIAN VILLAS}

Certainly it is widely known, and self-evident anyway, that the Californian bungalow style that swept our country between 1910 and 1930 was an import from the western United States. This unfamiliar form readily overwhelmed our long-established Victorian house types from which it differed in almost every respect. There is, however, one major point linking both types closely that does not seem to be widely realised - that our Victorian house style, by and large, had also come to us directly from the western United States, not from Victorian England as might be supposed. You will seek in vain in English towns for streets of free-standing, wooden, upright two-story or spreading one-story Victorian houses like ours. In England's crowded towns with their brick row-houses of Coronation Street or even among the classy suburban villas of Wimbledon they simply do not exist. But San Francisco and other western US towns are full of wooden Victorian houses lining street after street - and looking astonishingly familiar to New Zealand eyes.

One soon realises that these towns in the pioneering American West were equally newly-settled and were developing in the 1860s at the same time as New Zealand. Conditions of climate, landforms and plentiful supplies of timber were closely parallel to our own. A stream of influence from the vigorous US west flowed along our communication links with California, which were much shorter than those to the Old Country. Mail and passenger steamers on the San Francisco route from 1870 provided our closest connection with the rest of the world.

The American style of elaborately ornamented, baywindowed, high wooden villas gave expression to Victorian society's pride in property, and allowed a degree of ostentation which appealed to the image of the self-made man, a figure typical of the age on both sides of the Pacific. During the last quarter of the 19th Century, then, we copied freely from US-sourced pattern books of house
1 Stiffly upright with doublehung windows in weatherboarded walls and wooden shopfronts, the familiar Victorian character is seen here in pioneer buildings. Not a South Island mining town, but one in Colorado, USA.

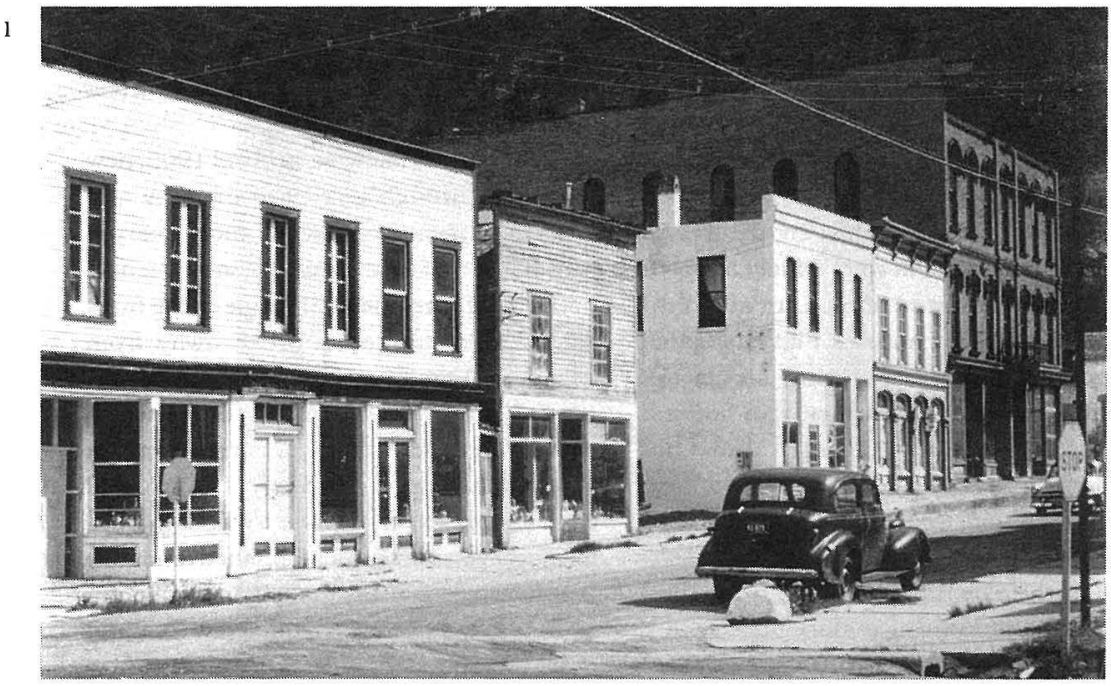




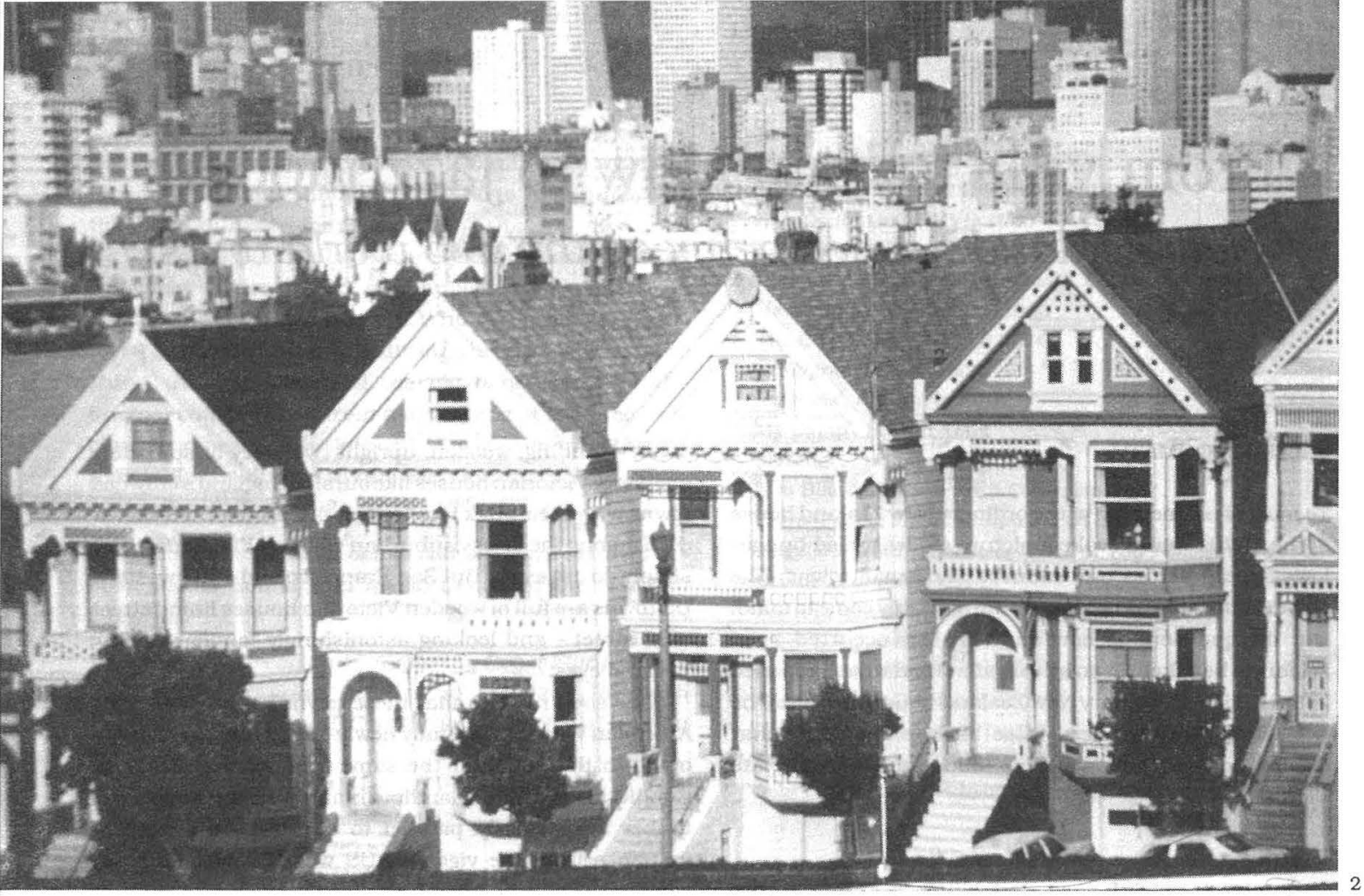

designs and endless variations of ornamentalwoodwork, all still displayed along many of our inner city streets. Thus we acquired distinctively American versions of English eclectic Victorian styles, revised to suit our social conditions, but adapted from English masonry models by way of translation into wooden construction by American architects and builders. Nor did our builders stop short at the surface of these ready-made fashionable house designs. The American technique of light timber framing, with thin studs and plates held together only by cut-wire nails and clad in weatherboards or shingles, had been developed in Chicago in the 1830s. By the 1860s these new methods were widely adopted in New Zealand and remain our standard construction for houses. Flat rusticated weatherboarding imitating stonework joints, as used on our Victorian houses, also appears to be of US origin as distinct from the bevelled boards used on farm buildings and occasional cottages in Britain.

In the Edwardian decade from 1900 our ubiquitous single-story villa, with a splayed bay window under a projected gable at one end of the front verandah, was a local form derived from similar US suburban types. This sometimes pompous image reflects the confident self-importance of the Edwardians, prior to the shock of the Great War. Within this first decade, alternatives arose to the closely packed houses in our cities by the extension of electric tramways to open up new suburbs with plentiful land, allowing the convenience of low-density single-story living. Increasing prosperity assisted attainment of the New Zealand ideal, the freestanding house on a quarteracre section.

In California likewise, around 1905, new freedoms through increased mobility and land expansion promised a more relaxed way of life, and saw the emergence of a new house type, the informal single-story bungalow. This marked a break away from decades of Victorian housebuilding in western US cities. A similar and fundamental change in house types occurred here in New Zealand within a few years, in local circumstances very similar to those in California. Given our long-established tendency to follow western US models in house design, it is small wonder that New Zealand quickly responded to the success of the new
2 The distinctive features of large splayed bays with double-hung windows, under bracketed gables on narrow frontages, in San Francisco's wooden Victorian houses. The view could stand as a typical $N Z$ urban area, without change. (Middleton, 'Man Made The Town')

3 Assured proportions and bold features of turn-of-the-century American style timber houses in Mt. Victoria, Wellington. Many comparable houses were imported as kitsets and erected by local builders. 
bungalow style in California by adopting it here. This new house form abandoned our established Victorian patterns in nearly every aspect - in scale, number of stories, window shapes and types, roof forms, ceiling heights, plumbing standard, ornamentation, even in colour.

\section{Californian bungalows}

How radical the low-slung Californian bungalow must have appeared in the context of our Edwardian towns just before the War! As might be expected, they were reviled initially by the establishment and especially by the English-orientated local architects who saw the bungalow as a brash intrusion from the upstart Wild West. But its popular success was rapid, here as in California. At a time of social changes, its frank use of simple materials and unaffectedly direct sheltering forms underlined a new freedom from conventions among the common people.

An unsophisticated product, it spoke of cosy domesticity, of a popular culture, and of an Arts and Crafts pleasure in humble construction. Above all the new bungalow form was eminently practical, economical to build, a natural for our temperate climate, and an artistic house for the common man. As well, there were many practical reasons for the change from villa to bungalow. Victorian high ceilings made heating difficult and were disproportionate in small rooms. The Arts and Crafts movement from the late 19th century had been promoting very low ceilings, as in English cottages: this helped pave the way for acceptance of the bungalow's low lines. Moreover, high walls were expensive, needing more materials inside and out.

4 The characteristic rhythm of vertical Victorian bays and gables in a Marjoribanks Street, Wellington, group.

5 Familiar forms, proportions and language - not English, but a San Franciscan rusticated timber semidetached 'duplex'. (Baer, 'Painted Ladies')
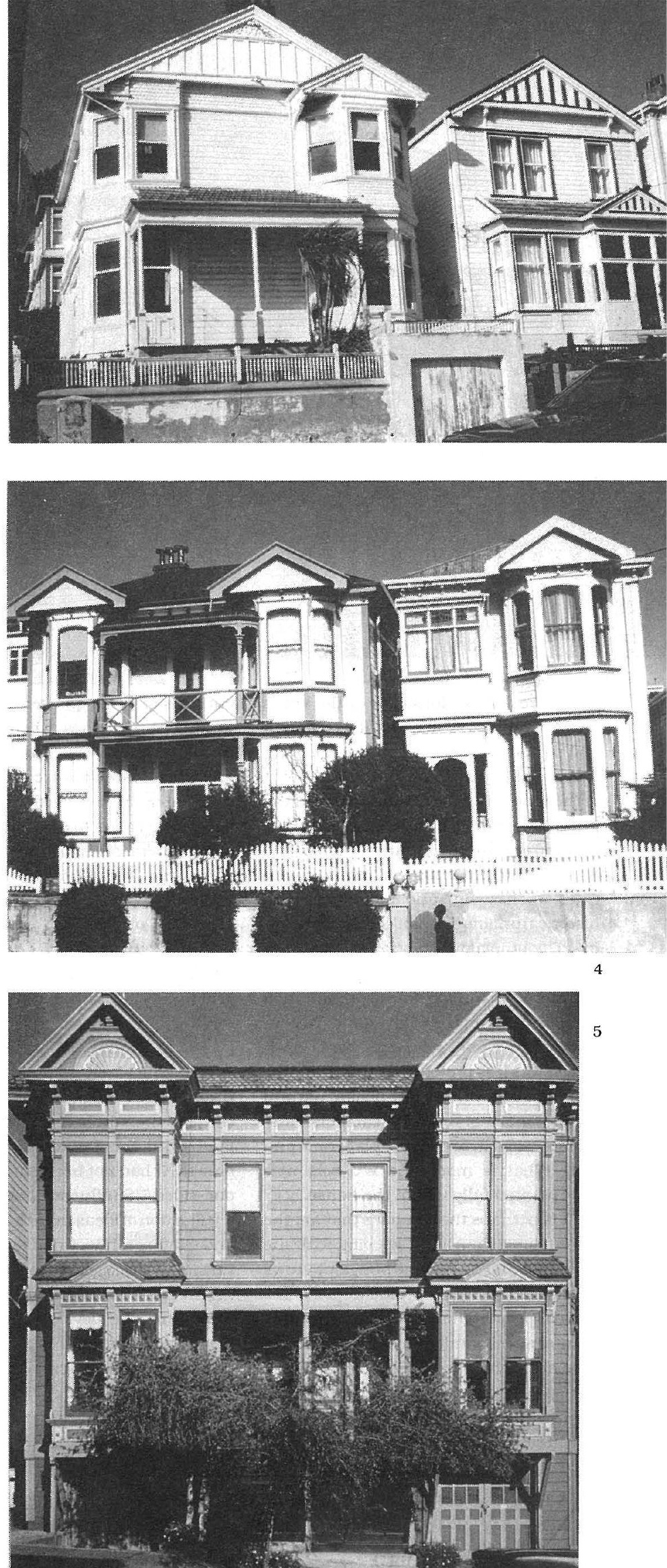


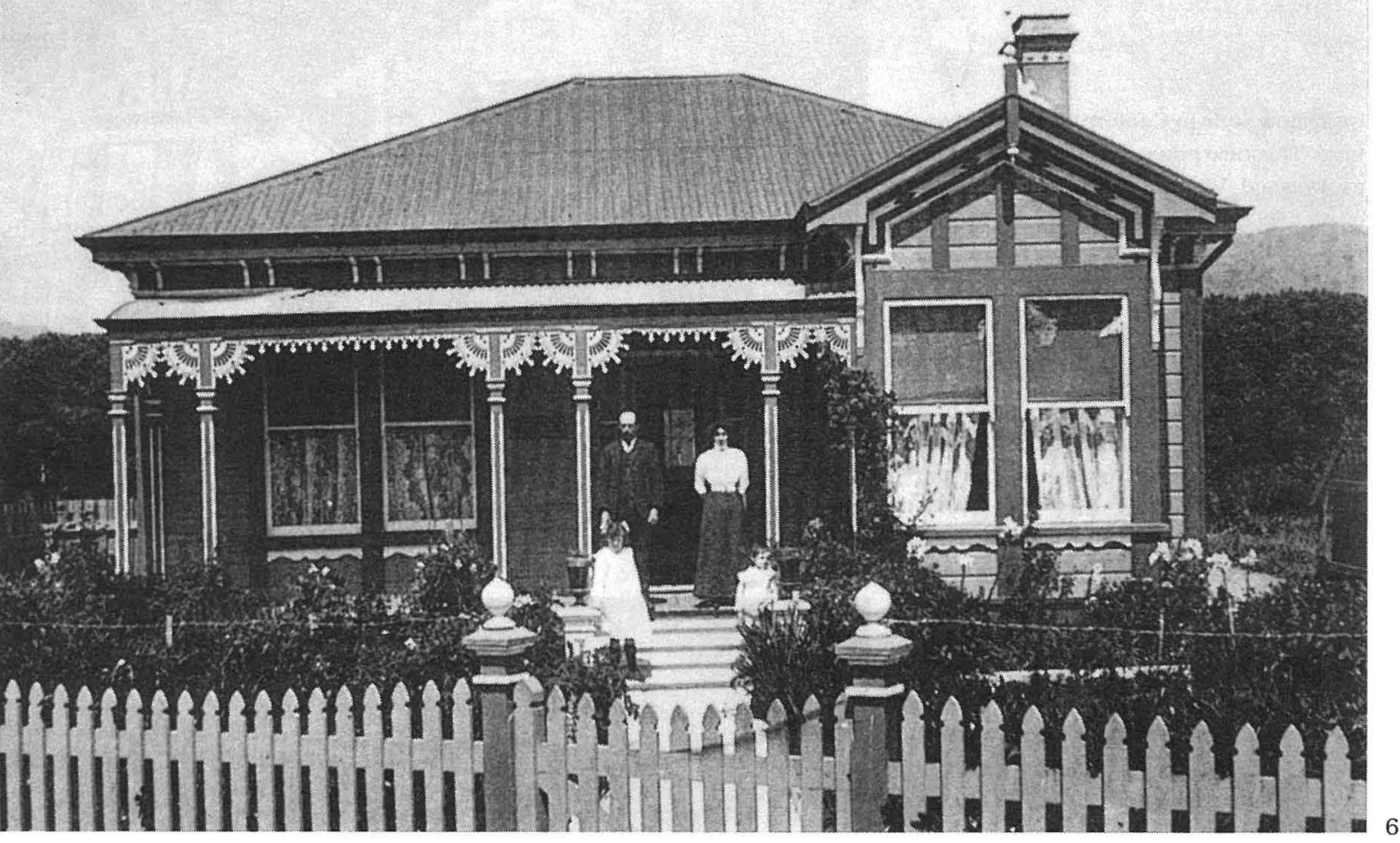

The restrictive formality of the villa's face to the street, keeping its verandah and parlour bay even when facing south, was out of key with the less formal spirit of the times. The more casual style of the bungalow enabled living rooms to face the sun and entrances to be at one side. There was a similar reaction against elaborate exterior ornament and mouldings with historical origins that had lost their meaning. The bungalow's restrained style and subdued detail was a return to simplicity. Its internal planning was more informal and flexible than the villa's standard central passage and string of rooms each side. It was less pretentious than the villa, more homely with its low nooks, natural wood panelling, built-in cabinets, and stained wood in archways, plate rails and trim. What is more, the WC was now incorporated fully within the house.

It is perhaps the windows that are the most telling change. In keeping with the low horizontal lines of the bungalow, rows of casements side by side replace the vertical proportions of the villa's doublehung sashes. Window areas are generally considerably reduced: to many people the large glass area of Victorian tall bay windows was excessive for sun or privacy, and in practice was reduced greatly with curtains or three quarter-drawn blinds. Double-hung sashes, when aged, rattled in the wind or were prone to jamming; and when sashcords broke they were left inoperable. Side-hinged casement windows were easier to deal with; and when English-type fanlights were introduced above them rainproof ventilation was achieved. At the same time fanlights provided one of the hallmarks of the New Zealand bungalow: the universal leadlights, ranging from simple diamondgrid to flowing patterns in textured and multi-coloured glass.

From about 1910 all these changes were taking place, gradually at first; but through the 1920s the bungalow became the predominant house type in New Zealand until the Depression stopped all growth. It had not been entirely a case of one-sided US influence however. Crossfertilisation of ideas from the English Arts and Crafts architects led to distinct local variants, perhaps the most pervasive being the curved or segmental bow window. This attractive device came to be employed ad nauseam in England on endless rows of brick 'semi detacheds', but stems originally from Charles Voysey's fresh reworking of an old form for new houses in Surrey in 1897.
6 The early colonial verandahed cottage acquires a US-style splayed or square bay at one end and becomes our commonest house type, the New Zealand 'villa'. With multi-colour banded paintwork and verandah lacework in cast iron it is an emphatic presence at odds with the wide open spaces. (Alexander Turnbull Library).

7 Afull-blooded large Californian bungalow in Lower Huit, imported precut from the USWest Coast about 1920. The timbers are redwood - even the supplied scaffolding! All the hallmarks of the bungalow style are here: multiple gables at the front, gable at the side, wide overhangs, open rafters at eaves. Corner porch was originally open.

8 A charmingly simple early bungalow in brick, about 1914 in Hataitai, with typically US 'shed' dormer window (lighting only roofspace) and generous porch. Repetitions of stubby piers and gentle arcs, inverted in balustrade and fence, unify house and its setting.

9 The everyday architecture of the bungalow : simple lines with a light touch and unsophisticated grace in long, low rooflines. Fanlights over casement windows in Kensington Ave., Petone. 


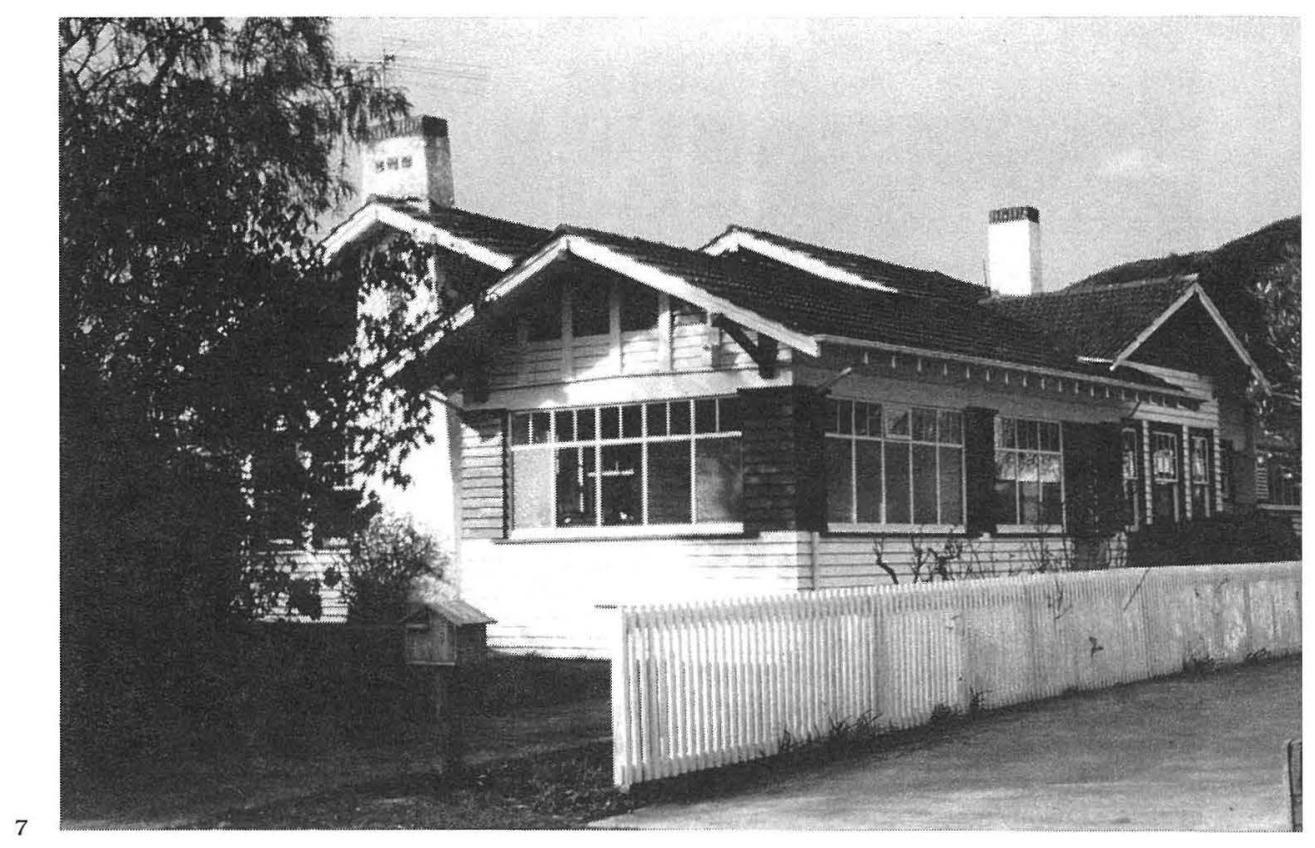

The New Zealand bungalow manner, at its best, became a genuine folk style clearly suited to our national character - practical minded, down to earth, sensible in its use of materials in obviously wooden forms, but also generous, welcoming, direct and open. It is regrettable that this popular house type was shunned by the architects of the time, and thus was deprived of the design skills and imagination which could have developed to its full potential this convincingly rational and generously warm regional style.

\section{Bungalow ORIGINS}

Before leaving the bungalow it is of interest to trace briefly the term's origins and passage of the type to this country. The word comes from the Hindu bangla, a native dwelling of Bengal of a type adapted by the English in India for their own use in the late 17 th century. A simple one-story building, double-roofed to include a verandah and with civilised provisions internally, it became a standard house type built for British colonial administrators throughout the British Empire - including the central block of our Treaty House in Waitangi, shipped from Sydney in 1833 to house the British representative here. This compact house

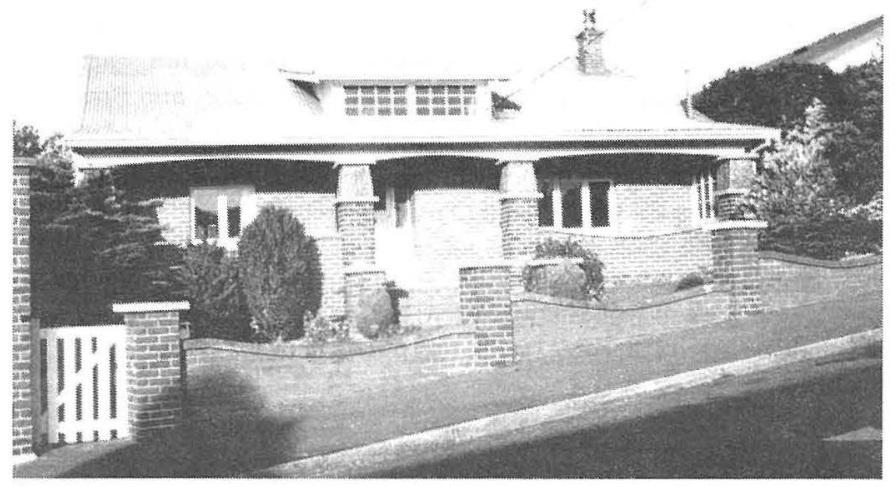

8

9

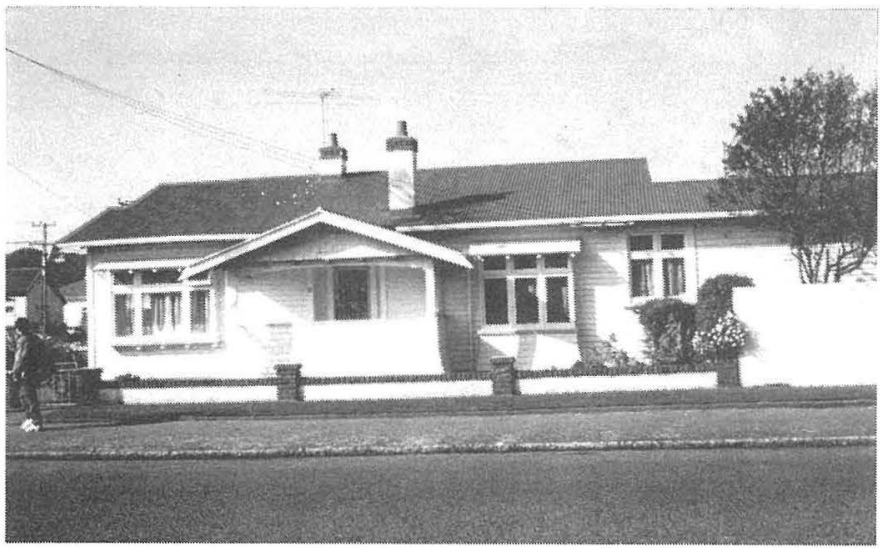




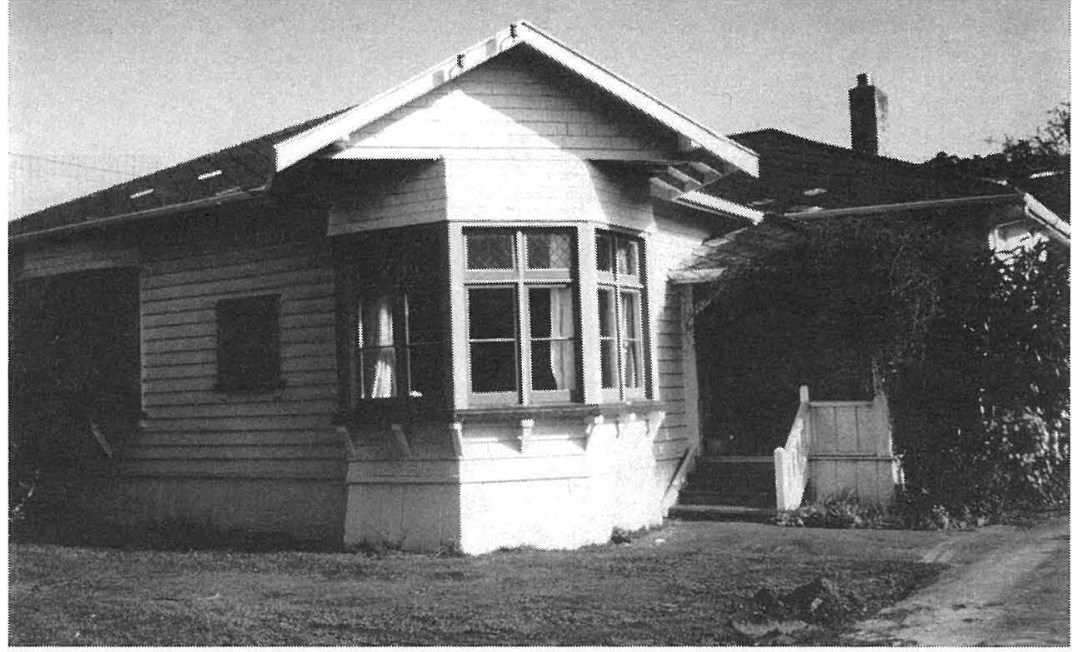

10

type was widely adopted in our pioneer days, together with that other India-derived benefit, the 'verandah'.

In England the simple 'bungalow' enjoyed a vogue from about 1860 , especially as a rustic or seaside retreat. In turn, the US-eastern states followed the English model for holiday houses on Cape Cod, and then across the continent by the 1880 s. In California a particular mix, blending older Spanish hacienda local types and Japanese roof forms with Arts and Crafts design features, was developed from the early 1900s into the characteristic California bungalow we know so well.

\section{ENGLISH STYLE}

Individually custom-designed houses fall outside our present scope in this review; but it should be noted that some interaction did occur between the ordinary bungalow mode and architects' designs for the well-to-do. In the interwarperiod most architects favoured the well developed English prowess in domestic architecture, exemplified by the Arts and Crafts or Free Style house designs by Edwardian masters such as Voysey, Lutyens and Mackintosh. Their design qualities were at a different plane from those of the bungalow, being typified by a quiet and restrained style of grace and strength, high roofs and fine gables, the avoidance of pretension and fussiness, and with good craftsmanship and materials honestly used. A hybrid style was developed in New Zealand, combining bungalow carpentry details in walling and open eave rafters with steep English asymmetrical gable roofs and Arts and Crafts bay windows, often with bellcast skirts.
10 Post-Edwardian transition to the bungalow, c.1917. This Hutt Road house retains the earlier style's bay window under a gable, but with bungalow casement windows instead of double-hung sashes. Informal side entry, frankly exposed rafters and struts and shingled gable areas all point to the bungalow style. A characterful design fitting the epigram "bungled villa or vilified bungalow?"

11 Variations on the NewZealand bungalow theme. This Newtown group displays a range of favoured elements: dual gables, broad front porch or side entry, bellcast gable ends on stub brackets, rafter-toothed eaves, and planked window hoods. All have the distinctive bow window.

12 This Lower Hutt house epitomises the development of our regional bungalow form. Its relaxed informality expresses the quality of comfortable wellbeing which comes very close to a widely-held Kiwi ideal.

13 The essence of English style in Voysey's own house of 1900 outside London. His powerful simplifications of traditional forms, strong gables and bands of casements were influential worldwide.

14 A Remuerahouse by R. Binney in 1922 builds on Englishqualities, marrying crisp geometry after Voysey to a rich variety of materials in the manner of Lutyens. (Dept of Education).

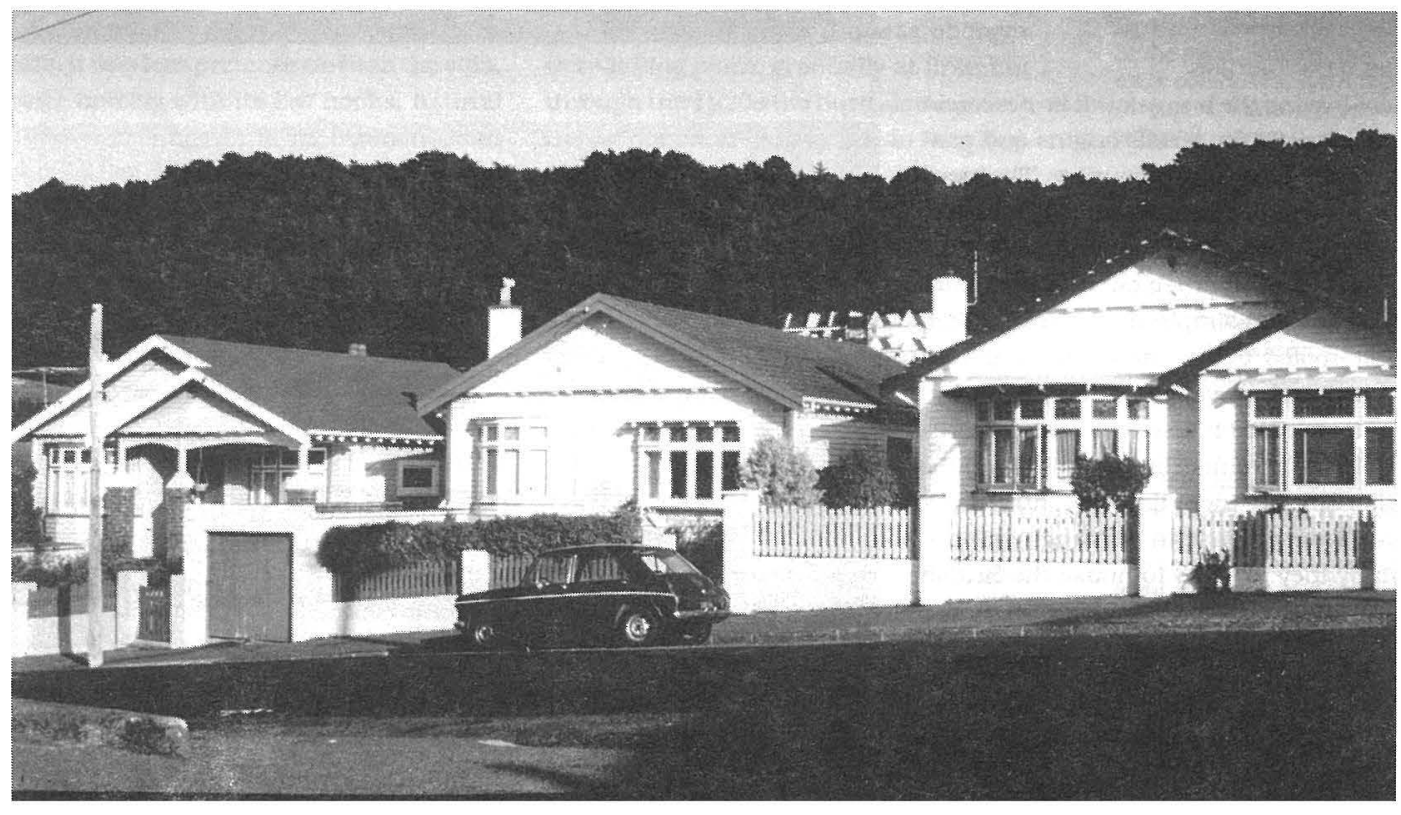




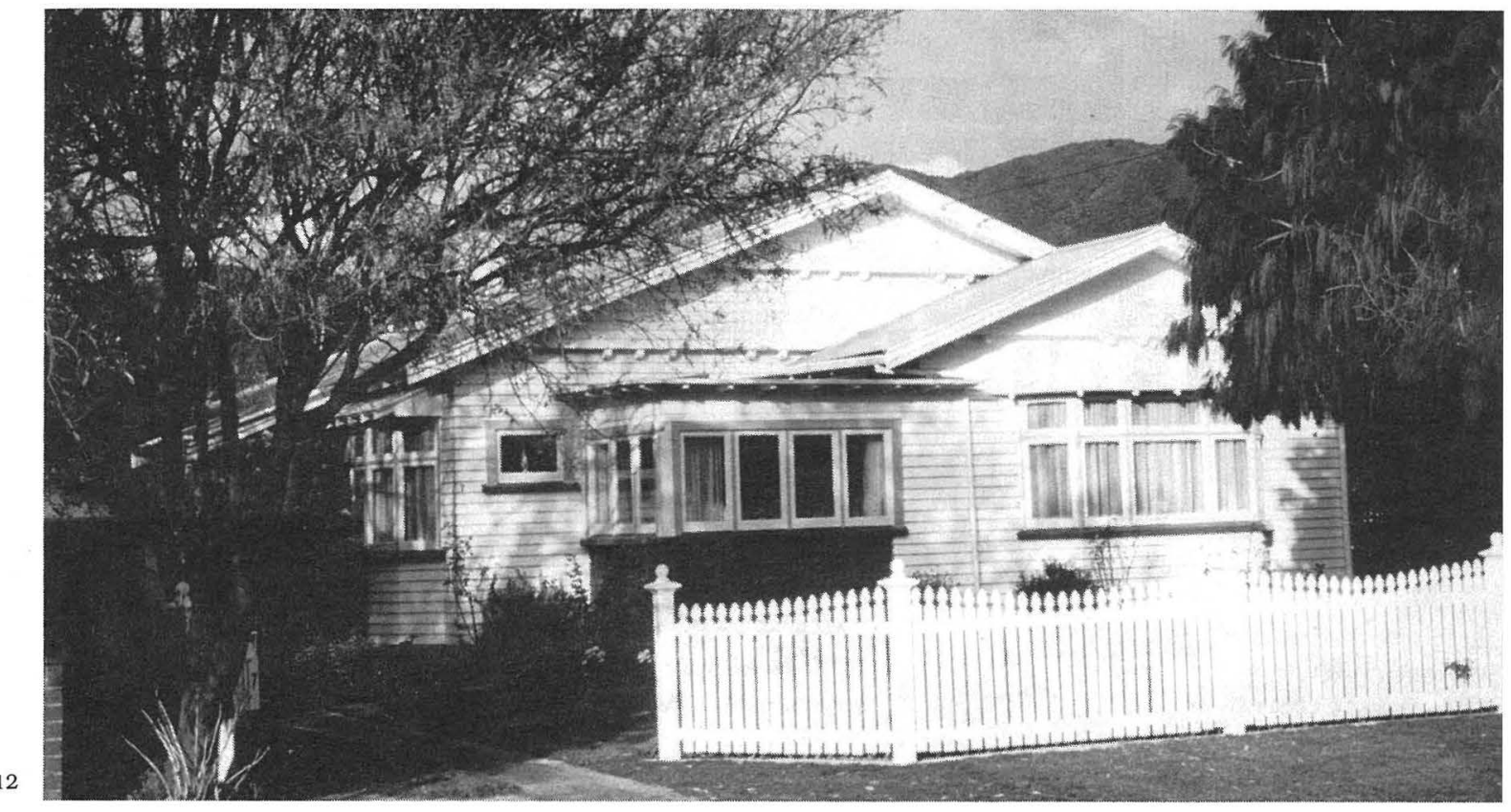

AMERICAN WAYS

The architects' English-style houses, albeit high in quality, were a very small minority in the general scene. The most typical character of New Zealand's ordinary domestic buildings and towns was United States-derived between the 1870s and 1930s, as we have seen. It is perhaps disconcerting to realise how persistent was this American formative influence throughout the very period in which sentiment about our British ties is commonly depicted at its highest. It appears that many of our forbears referred to Britain as 'Home', and rendered homage to 'The Old Country' in sentiment and loyal support, while in the practicalities of life in this new land they marched to a different drum - that of our neighbours on the US West Coast. This influence appears strongly in many fields, particularly those affecting popular tastes, and reflects the many parallels between our local conditions and those in America's experience. Clearly, New Zealand found attractive answers ready-made in the US to many of the shared problems of inhabiting a new world and of making fresh starts in similar environments. The US influence extended early to our way of life and broad aspirations. Fruitful study might be given to the depth of US influence on New Zealand culture at the critical periods in which we are commonly thought to have been 'more British than the British'. Perhaps our forefathers did not care to admit how much they owed to America in fact.

THE THIRTIES

After the mean Depression times, a make-believe reaction

13
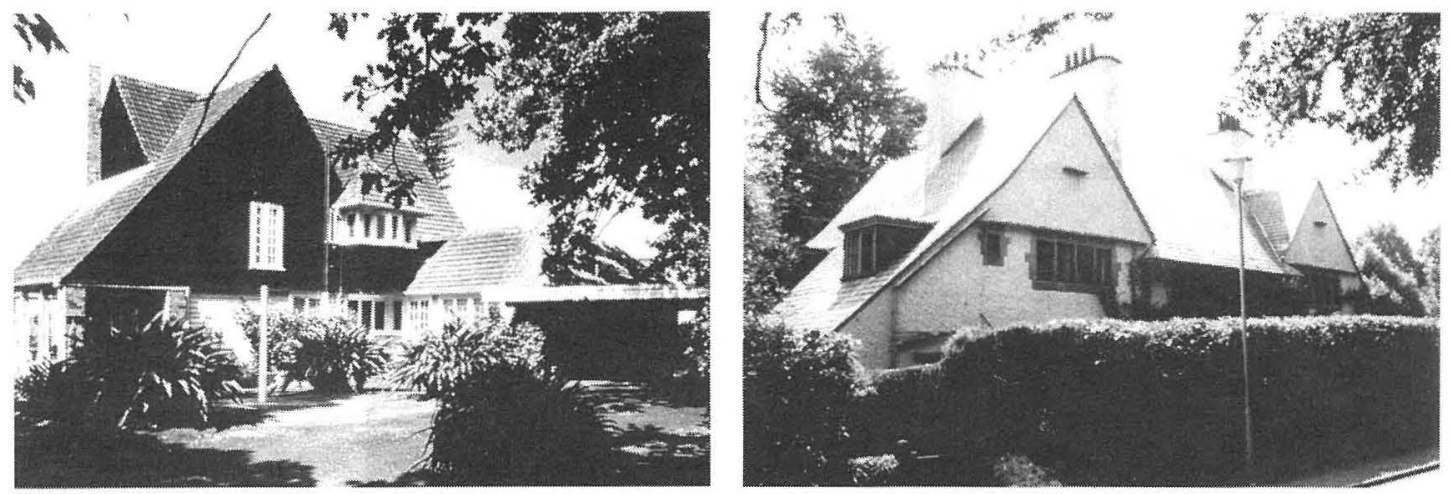


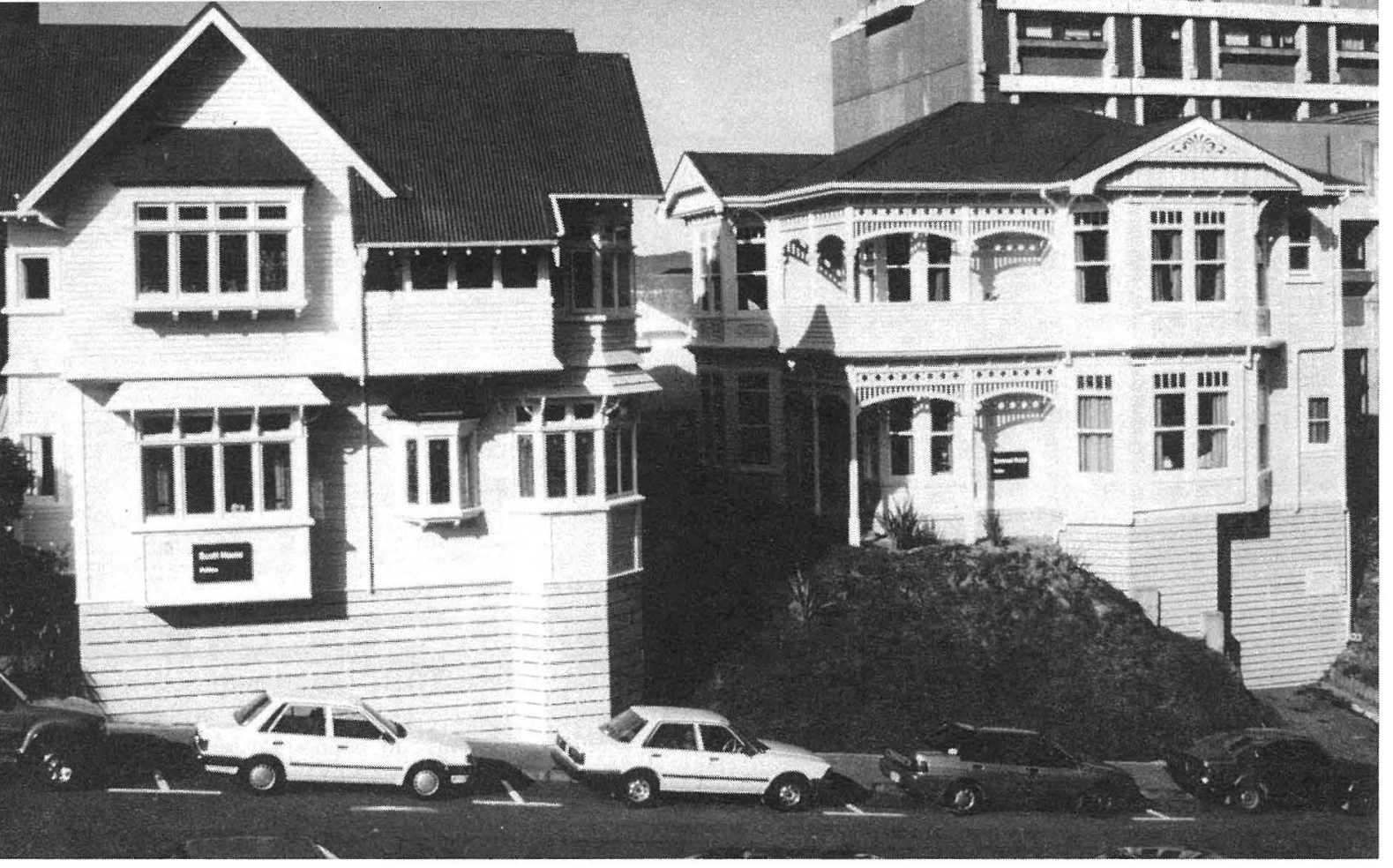

is understandable. It took the form of a short-lived decorative style known as Jazz Modern, again America-sourced, which combined unsophisticated parodies on the austere functionalism of the 1920 s Modern European architectural mainstream, with Hollywood overtones and streamline motifs. The style was propagated by popular US books of house plans and designs which were very influential on local builders' versions. To architects there was something 'not quite proper' about this superficial fashion.

More significant by far was the State Housing design policy adopted in 1936 which had the effect of abruptly diverting the course of design development away from the popular low-pitched bungalow type and towards an English cottage model. With the highest of intentions, the Housing Department engaged local architects to produce the first basic range of house designs within the department's guidelines. These stipulated that the houses were to have 'dominant roof proportions' and the general character of traditional English cottages. This was the English Style in which local architects were well versed; and many of these early state house designs were of high quality. But the design policy meant that

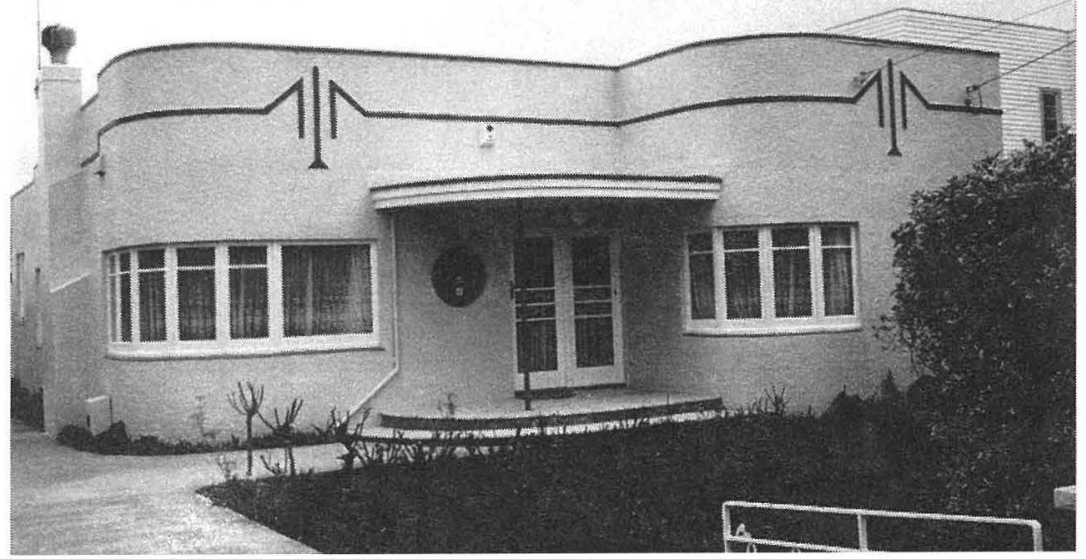

15 This peak of Edwardian composure (right) summarises Victorian forms, which were equally applicable to one or two stories. Adjoining it, in clear contrast, a transitional hybrid of around 1920 combines English-style windows and gables with bungaloidcarpentry details. The Scott and Somerset houses resited at Victoria University make a perfect museum couple.

16 Thepost-Depressionreaction pro duced a spree of populist ventures in the streamline mode. 'jazz modem' parodies on the pure geometries of Functionalism. Hollywood make-believe is laid over the bungalow plan for this Lower Hutt house, with ornaments of execrable device.

17The later 1930s held the exciling promise of "the future", exemplified by this dramatic house in Lower Hutt. Here is glamorous facadism, again straightfromUS books of designs. One of a jaz: modem nest in Marina Grove, echoing the brief era of futuristic World Fairs before the war.

18 A 1937 architect's design in free English style, showing many of the pleasant elements which became standard state house features in cottage form thereafter. House by Bernard Johns in Lower Hutt. 
the opportunity of pursuing the bungalow's potentially natural growth as an indigenous New Zealand type was lost. Housing Department standard construction changed the economic bases of the housebuilding industry: concrete roof tiles and precast piles, terrazzo sink benches and stock profiles for interior trim. The mould was set for thereafter. Stout Centre Conference on 'The In-Between Years', on the 15-16 August 1992 the typical New Zealand house for decades

This paper was presented at the

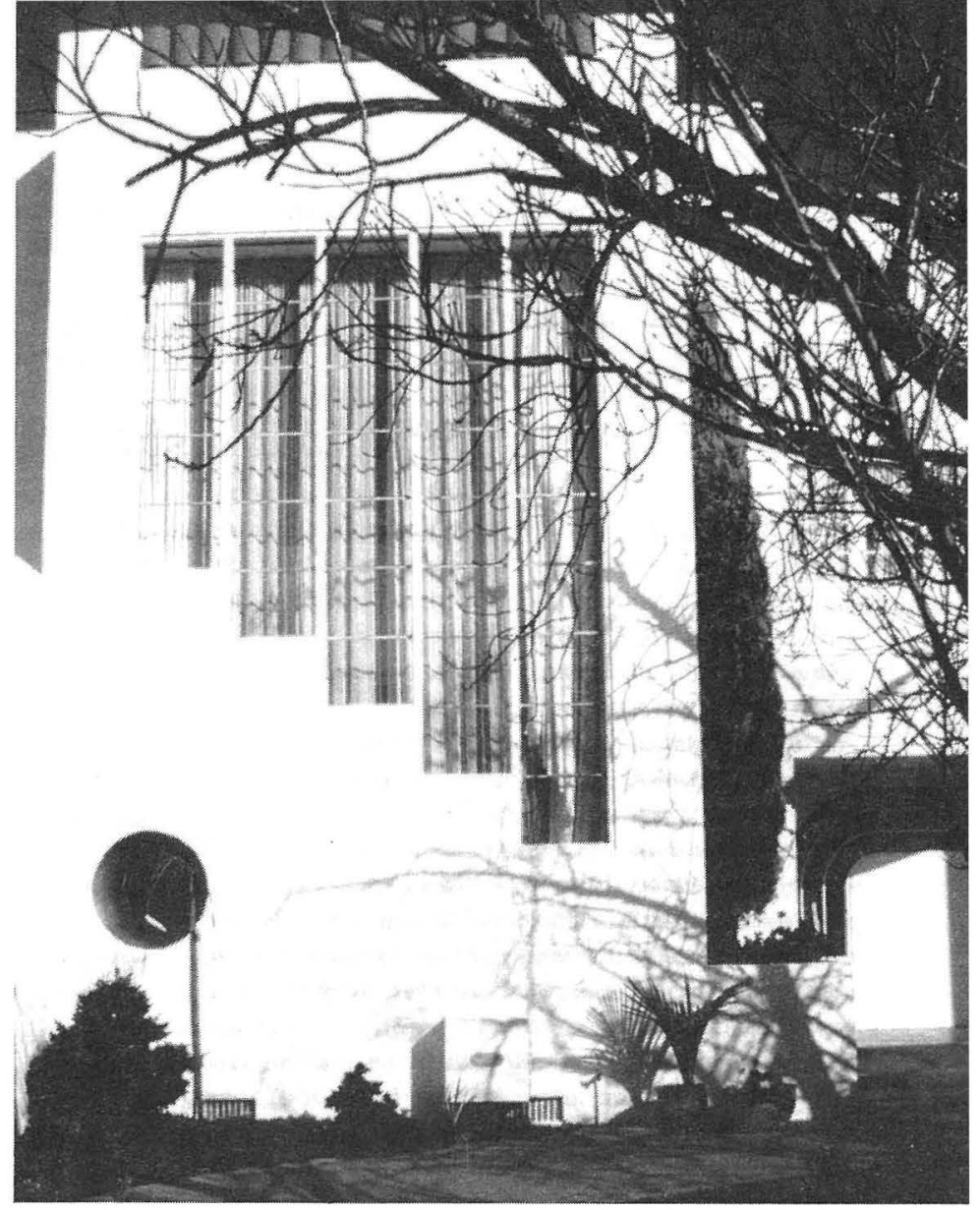

18

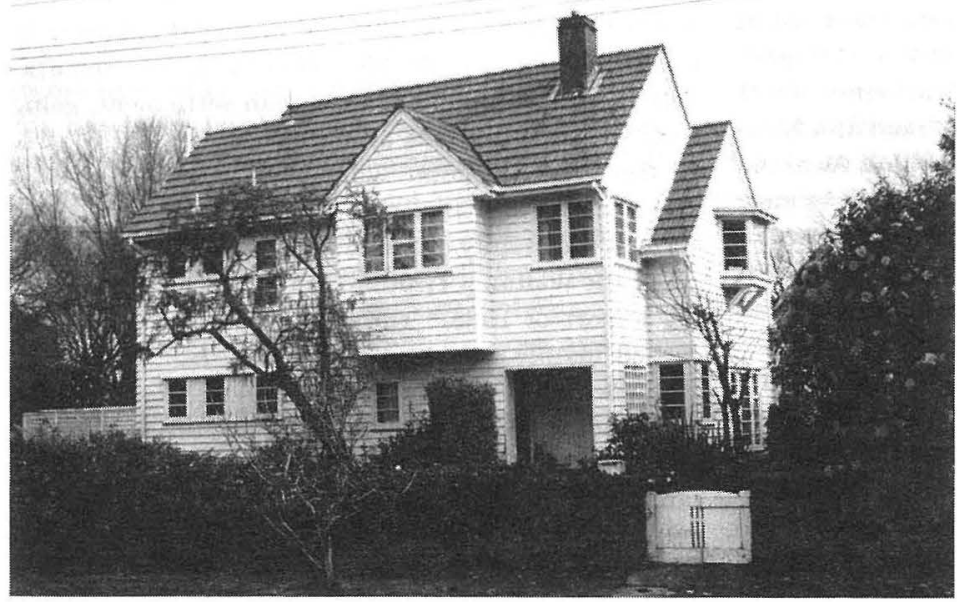

Bill Toomath has been a practising architect for more than 35 years. He designed the medalwinning Teachers' College at Karoriand many othereducational buildings and hillside houses around Wellington. He also directed the School of Design at Wellington Polytechnic for ten years until 1989. He spent severalyears in the US in the 1950s, studying at Harvard and working with I.M. Pei in New York.

Thirdgeneration Wellingtonian, he yet recalls an American flavour in his 1930s' childhood-Longfellow's 'Hiawatha' readings, Chatauqua easel board, Life and Saturday Evening Post magazines, Tom Sawyer role models, Pontiac and Chevrolet family cars, and so on. 